\title{
THE DISCURSIVE FEATURES OF THE COLLABORATIVE INTERACTION OF ADVANCED LEARNERS OF SPANISH: A SOCIOCULTURAL PERSPECTIVE
}

\author{
Marta Antón and Frederick J. DiCamilla \\ Indiana University-Purdue University, Indianapolis \\ manton@iupui.edu \\ fdicamil@iupui.edu
}

\begin{abstract}
Resumen
El presente estudio investiga la interacción colaborativa entre estudiantes anglohablantes matriculados en un curso avanzado de español al nivel universitario. La investigación queda enmarcada en la teoría sociocultural sobre el pensamiento y la lengua, basada en la obra del psicólogo ruso Lev Vygotsky (1978, 1986). Se examinan rasgos específicos de la interacción que ocurre mientras realizan tres tareas de redacción en colaboración (repetición, clases sentenciales, verbos modales, etc.) a fin de determinar las funciones cognitivas y sociales de sus enunciados. El enfoque de la investigación es determinar cómo el lenguaje, bien sea lengua materna o segunda lengua, funciona como el modo principal de mediación en el proceso de aprendizaje de una segunda lengua, particularmente en el aula. Se exploran dos elementos claves de una colaboración eficaz, el andamiaje y la intersubjetividad, con el propósito de comprender cómo usan el lenguaje los alumnos para facilitarse andamiaje entre ellos y para lograr y mantener intersubjetividad.
\end{abstract}

PALABRAS CLAVE: teoría sociocultural, interacción en el aula, español, adquisición de segunda lengua, trabajo en grupo.

\begin{abstract}
This study investigates the collaborative interaction of English-speaking students enrolled in a university upper-level Spanish course. We have framed our research within the sociocultural theory of mind and language based on the work of the Russian psychologist Lev Vygotsky $(1978,1986)$. We examine specific features (e.g., repetition, sentence types, modal verbs, etc.) of student interactions in order to determine the social and cognitive functions of their utterances while performing three collaborative writing assignments. The focus of this research is how language, whether L1 or L2, functions as the principle mediating device in the process of learning a second language, particularly in a classroom setting. Two key elements of effective collaboration, scaffolding and intersubjectivity, are explored in order to understand how students use language to provide each other with scaffolded help and to achieve and maintain intersubjectivity.
\end{abstract}

KEY WORDS: sociocultural theory, classroom interaction, Spanish, second language acquisition, group work.

\section{Introduction}

This article reports on an investigation of the collaborative interaction of adult native speakers of English enrolled in an upper-level Spanish course. We examine specific features (e.g., repetition, sentence types, modal verbs, etc.) of student interactions in order to determine the social and cognitive functions of the subjects' utterances in the performance of three collaborative writing assignments. The research addresses the question of how language, whether native language or target language, functions as the principle mediating device in the 
process of learning a second language, particularly in a classroom setting. We focus on two key elements of effective collaboration, scaffolding and intersubjectivity, and address primarily the following two questions: How do students use language to provide each other with scaffolded help? How do students use language to achieve and maintain intersubjectivity? The theoretical framework for our research is the sociocultural theory of mind and language based on the work of Lev Vygotsky $(1978,1986)$ and his adherents.

\section{Theoretical background}

\subsection{Sociocultural Theory}

According to Vygotsky (1981: 162):

Any higher mental function necessarily goes through an external stage in its development because it is initially a social function...Any higher mental function was external because it was social at some point before becoming an internal, truly mental function.

In the earliest stage of life the development of higher psychological functions appears on the social plane, i.e., in collaboration with adult caregivers or other knowledgeable members of the child's culture. The transfer of functions from the social (or interpsychological) domain to the cognitive (or intrapsychological) plane occurs within the zone of proximal development (ZPD), which is defined as

the difference between the child's developmental level as determined by independent problem solving and the higher level of potential development as determined through problem solving under adult guidance or in collaboration with more capable peers. (Vygotsky, 1978: 86)

It is within the ZPD that cognitive development occurs, not only during this early stage of life but throughout one's entire life. Through collaboration with others in our culture we become self-regulated. In self-regulation, the control of one's behavior does not reside in immediate stimuli (a case of being object-regulated) nor in another person (a case of other-regulation) but rather in an internally self-generated cognitive plan. Not a permanent level of development, self-regulation is relative to specific tasks and is best characterized as the attainment of an individual's potential for development in innumerable endeavors realized through complex interactions with others in one's culture mediated principally by language.

One of the chief areas of inquiry in sociocultural theory has been concerned with the question of how language serves to mediate human activity both on the interpsychological plane in the form of social speech (and/or writing) and on the intrapsychological plane in the form of private speech, i.e., speech directed toward the self, serving a cognitive rather than a communicative function. In the latter domain, for example, the content, elliptical form, syntactic structure, and other formal linguistic properties (e.g., tense, aspect, modality, reference) of speech and writing directed to oneself for the purpose of planning for and guiding oneself through a variety of tasks have been studied (for example, DiCamilla and Lantolf, 1994; Frawley and Lantolf, 1985; John-Steiner, 1987; McCafferty, 1992, 1994; Pellegrini, 
1981; Wertsch, 1979). With regard to the interpsychological plane, i.e., the collaborative interaction of individuals, researchers have investigated how the language of expert or otherwise more knowledgeable peers and of learners best serves the goal of helping learners achieve self-regulation in the performance of some task (see, for example, Ahmed, 1994; Aljaafreh and Lantolf, 1994; Behrend, Rosengren and Perlmutter, 1992; De Guerrero and Villamil, 1994; Diaz, Neal, and Vachio 1991; Donato, 1994; Ohta, 1995; Radziszewska and Rogoff, 1991; Schinke-Llano, 1994; Villamil and De Guerrero, 1996; Wertsch, Minick, and Arns, 1984). In summary, throughout one's life speech is used to regulate others and to regulate ourselves and serves as a psychological tool in organizing functions (e.g., voluntary attention, perception, planning, memory, conceptual thought, evaluating) critical to mental activity.

\subsection{Scaffolding and Intersubjectivity}

The concept of scaffolding originates with the work of Wood, Bruner, and Ross (1976) and serves as a metaphor for the interaction between an expert and a novice engaged in a problem-solving task. According to Wood et al. (1976: 90), scaffolding involves the expert taking control of those portions of a task that are beyond the learner's current level of competence, thus allowing the learner to focus on the elements within his or her range of ability. As Stone (1993: 170) points out, a «persisting limitation of the metaphor of scaffolding relates to the specification of the communicative mechanisms involved in the adult-child interaction constituting the scaffolding». Further, Stone (1993: 170) points out, and we would agree, «[t]hese mechanisms are crucial to Vygotsky's theoretical framework». That is, the use of language (and other semiotic systems, e.g. gestures) is the critical device for mediating cognitive development. It is within the ZPD where scaffolding occurs, or where semiotically mediated interactions lead to development ${ }^{1}$. Stone goes on to discuss various ways of analyzing scaffolding as semiotic interactions. Among other things, he discusses the role of utterances which «presuppose some as yet unprovided information», (Stone 1993: 171) which is what Rommetveit $(1974,1979)$ refers to as prolepsis. Such utterances serve to challenge a listener/learner to partake of the speaker's/expert's view of a problem-solving situation, that is, to construct with the expert a shared perspective or what Rommetveit (1985) calls intersubjectivity. According to Wertsch (1985: 59), intersubjectivity is achieved when «interlocutors share some aspect of their situation definitions», i.e., when individuals working in collaboration define the objects (both concrete and abstract), events and goals of a task in the same way. Moreover, the overlap in definitions of situation that constitute intersubjectivity may occur at many different levels, thus creating various levels of intersubjectivity (Wertsch 1985: 159) $)^{2}$.

1 We do not consider the concept of the ZPD and that of scaffolding to be equivalent. For us, scaffolding describes the strategic use of language among learners in our study that can foster language learning. The ZPD is a more robust theoretical concept that describes how development occurs and how it can be understood and assessed. For more on the commensurability or lack thereof of the ZPD, scaffolding, and related concepts, see Kinginger (2002), Lantolf and Thorne (2006), and Stetsenko (1999).

2 Matusov (1996: 29) argues that intersubjectivity is better understood as the «coordination of individual activity» than as sharing, noting that consensus is not always achieved or even the goal of joint activity. This perspective 


\subsection{Collaboration}

Three main sociocultural concepts are relevant to this and other studies of collaborative interaction. These are that social interaction leads to cognitive development, that language and other cultural tools mediate cognitive functioning, and that development advances through the Zone of Proximal Development (Lantolf \& Thorne, 2006). Sociocultural studies of collaborative talk in the L2 classroom have mostly focused on how language mediates learning among individuals. The work of scholars such as Aljaafreh and Lantolf (1994), De Guerrero and Villamil (1994, 2000), Donato (1994), Ohta (2000, 2001), Swain and Lapkin (1998), and Villamil and De Guerrero (1996) has contributed to our understanding of how dialogue functions as a cognitive tool not only between teachers and their students but also between students working in collaboration to learn a language.

Several studies have focused on the nature of collaborative interaction among learners of Spanish while performing various communicative tasks in a classroom environment. Platt \& Brooks (1994) examine collaborative interaction in ESL and FL classrooms showing that besides negotiated interaction the task elicits important strategic activity. The joint speech activity that develops during problem-solving tasks does not merely serve the purpose of transferring messages, but it gives learners opportunities to «enhance the psychological processes that underlie regulation or psychological autonomy» (Platt \& Brooks, 1994: 508).

Brooks \& Donato (1994) also examine learners'talk during a problem-solving task. They describe how speaking activity serves as a strategic psychological tool for «cognizing and constructing tasks, meanings and shared situational definitions» (263). In particular, they illustrate how learners'talk serves three functions of speaking: speaking as object regulation, speaking as shared orientation, and speaking as goal formation. The authors argue that, although this kind of talk is often discouraged in second language classrooms because it is seen as irrelevant and most often it takes place in L1, its occurrence is important in that it allows learners to establish intersubjectivity. The analysis of discourse within the sociocultural framework shows the «impossibility of discussing L2 performance apart from cognition (e.g. planning, monitoring, etc.) as is often done in second language acquisition research» (271). Since cognition is dialogically constructed, it is possible to observe it directly in interaction.

In a follow-up study, Brooks, Donato \& McGlone (1997) analyze the development of certain features of learners' language across tasks including metatalk or talk about their own talk, metacognition or talk about how to do the task, students use of English, and students whispering to themselves. They found a general decrease of these features as learners gained familiarity with the task. They observe how the use of English progressively disappears from the interaction. What these findings imply is that learners achieve self-regulation in tasks when they have opportunities to engage in similar tasks across a period of time.

Buckwalter (2001) studies social and cognitive aspects of error repair during collaborative interaction among learners of Spanish. She observes that, much as it happens in L1 interaction, participants show a marked preference for self-repair and self-correction. Collabo-

merits a lengthy discussion which is not possible in the current paper. For our purposes, we feel justified in focusing on that aspect of intersubjectivity that does involve creating a common ground of understanding by the participants in this study. 
rative repairs occur mostly with lexical problems. Private speech, repetition and rhetorical questions are mechanisms often used by learners for self-repair.

Along these same lines, the work of DiCamilla \& Antón (1997), Antón \& DiCamilla (1998), and DiCamilla and Antón (2004) has examined the collaborative interaction of beginning-level adult learners of Spanish in a classroom context working in collaborative writing tasks. The authors examined specific features (e.g., repetition, sentence types, modal verbs, etc.) of student interactions in order to determine the social and cognitive functions of the subjects' utterances in the performance of the three collaborative writing assignments. DiCamilla and Antón (1997) find that repetition plays a critical cognitive role in scaffolding and in creating and maintaining intersubjectivity. Based on the same set of data, Antón and DiCamilla (1998) explore the social and cognitive functions performed by the native language (L1) as a powerful tool of semiotic mediation both on the interpsychological (between individuals) plane and the intrapsychological plane (within individuals). At the individual level, L1 is used sometimes as the vehicle of private speech when learners face a cognitively difficult task.

An important discussion of the concept of microgenesis as method and object of study is provided by Gánem Gutiérrez (2008) in her analysis of group/pair interaction during the completion of problem-solving tasks. She identifies three phases in microgenetic episodes, which are defined as those sections of collaborative interaction that provide evidence of language use improvement. Microgenetic episodes present opportunities for joint construction of knowledge, which may result in language learning.

These studies have highlighted that collaborative activities in the classroom afford opportunities for learning through peer assistance and co-construction of knowledge. In all of them language is the main mediating tool used by learners to assist each other during the interaction. The present study adds to this line of inquiry.

\section{The study}

The present study builds on the studies presented above. We focus our attention on critical communicative and psychological functions of the language deployed by advanced L2 learners during a collaborative task. By looking at data from learners enrolled in an advancedlevel class, we present a better picture of the extent to which L2 may emerge at a higher level of proficiency as the principal semiotic system for mediating the performance of the task.

The data presented here is part of a larger study of language use during collaborative tasks among students with different levels of language proficiency. For this study we focus on five dyads of university-level English-speaking students of Spanish enrolled in fourthyear (advanced) classes $^{3}$, who were audio recorded while they were writing collaboratively a composition in Spanish. Collaborative writing was a regular classroom activity. In three occasions throughout the semester, the writing sessions took place in a language laboratory for the purpose of recording the interactions. These sessions were viewed, however, as a regular

3 We made no attempt to formally measure language proficiency. We use the label 'advanced' to refer to students enrolled in fourth-year classes. Students' background with the L2 varied widely, as it is often the case at this level. We realize that it is likely that actual proficiency levels will vary among the students included in the study. 
part of the class since the students were accustomed to meeting in the language laboratory for their Spanish classes.

Students were given a writing prompt and received no further instruction as to how to complete the task or what language to use when speaking to each other. They were asked to work together without relying on dictionaries, textbooks, etc. They were also instructed to write the same text each on separate sheets of paper. The recordings were transcribed verbatim.

\section{TRANSCRIPTION CONVENTIONS}

( ) Comments enclosed in parentheses.

.. $\quad$ Brief pause.

... Long pause.

.... Longer pause.

- Incomplete word.

[ Talk overlap

?? Uncomprehensible talk

\section{Data analysis}

We first present the results of a count of all words spoken by our subjects in English and in Spanish in order to gain an overview of the extent to which the two languages were used.

Table 1

\begin{tabular}{|c|c|c|c|c|c|}
\hline Fourth-year & Dyad 1 & Dyad 2 & Dyad 3 & Dyad 4 & Dyad 5 \\
\hline English (L1) & $1 \%$ & $3 \%$ & $1 \%$ & $0 \%$ & $3 \%$ \\
\hline Spanish (L2) & $99 \%$ & $97 \%$ & $99 \%$ & $100 \%$ & $97 \%$ \\
\hline & $(\mathrm{N}=834)$ & $(\mathrm{N}=943)$ & $(\mathrm{N}=1077)$ & $(\mathrm{N}=656)$ & $(\mathrm{N}=1099)$ \\
\hline
\end{tabular}

The results of the word count, presented in Table 1, clearly indicate that the fourth-year dyads used L1 very little. The percentages of L1 and L2 use across dyads are quite consistent. Almost all of their interaction was conducted in the L2. Although these results were not unexpected, the low frequency of L1 use among fourth-year students is somewhat surprising. It bears repeating here that students were not instructed with regard to which language to use in their interactions. Given this, advanced-level students chose overwhelmingly to use L2 as the principal mediating device for the task.

\subsection{Scaffolding}

Duff (2000) highlights the various functions of repetition for instructional and socioaffiliative purposes in foreign language classrooms. She calls for analysis of repetition «as an element of discourse that potentially unifies students (and teachers) in their common pursuit of learning» and that «scaffolds their learning by means of their interaction with other learners and with the teacher» (Duff, 2000: 135). In the episode below repetition emerges as 
one important communicative mechanism in the process of providing scaffolded help. Like workers, students construct and hold in place a working space, i.e., a space from which further construction develops. Repetition can function as the linguistic/communicative equivalent of a platform on the scaffold, a point from which plans, suggestions, and ideas can be tested in the ongoing performance of the task. In this episode, repetition serves the function of offering L2 utterances for evaluation by oneself and by others, accepting one's own and other's contributions to the text, providing a platform from which to think and add new material to the text. It is interesting to note that the same functions of repetition were observed with beginning-level students (DiCamilla \& Antón, 1997). The use of repetition as a crucial mechanism for the construction of scaffolding and intersubjectivity is even more revealing with advanced-level students since their level of L2 proficiency is high enough so that they do not need to repeat for lack of ability to express themselves in any other way, that is, repetition here cannot be attributed to lack of proficiency. It does not result from what might otherwise be considered as a necessary byproduct of limited vocabulary or limited proficiency in general. Of course, the proof of this is the occurrence of repetition in normal L1 interaction, when language proficiency is never an issue.

\section{EPISODE 1}

1. J: Conozco un bueno o un buen.. tengo que ..quiero evitar el, escribir otra vez 'museo' (I know a good one or a good..I have to..I want to avoid the, writing 'museum'

2. D: Ah. again)

3. J: ¿Conozco a un buen en Puebla?

(I know a good in Puebla?)

4. D: Conozco a..a un..no, no, conozco.. (I know ..one..no,no, I know..)

5. J: ¡uno!

$$
\text { (one!) }
$$

6. D: conozco uno

(I know one)

7. J: uno

(one)

8. D: conozco uno ..que.. en Puebla que es ma- más bueno (I know one..that..in Puebla that is be-better)

9. J: que es [maravillosa

(that is wonderful - feminine ending)

10. D: [un poco más (a little more)

11. J: maravilloso (wonderful - masculine ending)

12. D: que es maravilloso (that is wonderful)

13. J: casi no tenemos papel (we are almost out of paper)

14. D: oh, it's O.K. Podría, podría seguir, podría seguir con ah..ah..O.K conozco uno en Puebla que es maravilloso, que tú, tú debes ver, ahh, tú debes, ¿no? que debes ver (oh, it's OK. I could, I could continue, I could continue with, ah..ah..OK I know one in Puebla that is wonderful, that you, you must see, ahh, you must, no? that (you) must see 
15. J: que debes ver.

(that (you) must see)

In this episode the students are creating a dialogue about the things that they would do while on an imaginary trip to Mexico. They have decided that they will visit art museums. At this point they become involved in the resolution of a grammatical problem: how to use a pronominal form that would avoid further repetition of the noun museum. As we shall see, L2 forms are used not only to create the content of the text, but also to negotiate meaning and form of the text. L2 forms are also used here to carry out planning strategies with the purpose of improving the style of the composition.

The interaction that unfolds in 1 through 3 reveals how these two students negotiate form when jointly addressing the problem of how to express I know a good one in Puebla, referring to a good museum. By offering suggestions for each other's consideration, and evaluating forms posed by the other, they provide the necessary scaffolding to reach a satisfactory resolution. Repetition of forms plays a pivotal role in the construction of scaffolding in this episode. In $1 \mathrm{~J}$ offers two possibilities for the intended meaning un bueno o un buen. In $3 \mathrm{~J}$ repeats one of these options, un buen, in a question format thus offering the form for D's consideration. D's repetition of the form conozco a un in 4 seems to aid her to evaluate this form, which is rejected in the same line. The final repetition of conozco in 4 followed by pause seems to indicate that the search for the correct grammatical form continues. Repetition of conozco provides a safe place in the scaffold from which to try out new forms. In this case, it seems to play a strategic role in the discovery of the correct form, uno!, uttered by $\mathrm{J}$ in 5 with great excitement. Repetition of conozco plus the new form by D in 6 is sufficient to indicate that $\mathrm{D}$ accepts J's contribution as the solution of the grammatical problem at hand. Once the new form has been established and agreed on by both members of the dyad, it becomes part of the text that the students are sure of. Thus, it can be used now as the safe platform in the scaffold from which students can move forward and construct new text. This is what we see in 8, where D's repetition of conozco uno serves as the basis for adding new material que..en Puebla que es más más bueno. In 9, J uses repetition of que es to offer another alternative, maravillosa, which appears modified in 11 maravilloso. Again repetition of que es plus the new form by D in 12 serves the function of signaling acceptance of J's contribution. In 14, D uses an L2 form, Podría, which marks her intention to offer new ideas for a possible continuation of the text at the same time that she invites J to consider her ideas. As with English modals, the form podria works both at the cognitive and social level. What is interesting here, though, is that there is an initial failed attempt on the part of D to offer a possibility for the continuation of the text. After a long pause, the occurrence of the form $O . K$ in 14 seems to mark a reorganization of her thinking in the search for adding new material. Once again, D's repetition of the previous sentence conozco a uno en Puebla que es maravilloso provides the safe place in the scaffold from which to attempt new content que tú debes ver. Still in the same turn, 14, the new material tú debes is repeated and evaluated resulting in the more natural form que debes ver. This new material, with its revised form, is repeated in 15 by $\mathrm{J}$ as a way to signal acceptance of the new content and form.

The next episode further demonstrates that the linguistic and communicative devices observed in Episode 1 are commonly deployed by the students in the study. In this excerpt students are working on a composition about food in the US. The students agree to begin their 
composition by focusing on fast food. As the following analysis reveals, the students come to operate from points mutually constructed on a cognitive scaffold. In particular, we will see further evidence that repetition functions as the linguistic/communicative equivalent of a platform on the scaffold, a point from which hypotheses, i.e., possible plans for development of the composition, are proposed in the form of questions and suggestions marked for both politeness and hypotheticality.

\section{EPISODE 2}

1. D: En los Estados Unidos la gente, ah,..la gente les gustan la, la comida que se puede, como re-

(In the United States people, ah..people like the, the food that you can, like)

2. M: preparar

(prepare)

3. D: muy rápidamente

(very fast)

4. M: rápidamente y, y esto se refleja también en los restaurantes de comida rápida, sí (fast and, and this is reflected also in fast food restaurants, yes)

5. D: sí, de comida rápida, ¿cómo se llama? 'Fast food' ¿restaurantes de comida rápida? (yes, fast food, what is it called? 'fast food'fast food restaurants?)

6. M: sí, sí, 'fast food' (yes, yes, fast food)

7. D: OK. Entonces podríamos empezar como un, en los Estados Unidos, Estados ah, Unidos, ah, ¿se gusta? Podríamos usar el 'se' sí, 'se' impersonal (OK. Then we could begin like a, in the United States, States, ah.. United, ah, they like? -wrong form- We could use 'se'yes, impersonal 'se.')

8. M: No, le le gu- con gusta creo que no, no, le..en los Estados Unidos, ah, ah.. (no, to them, to them li- with 'gusta' I don't believe so, no, to them..in the United States, ah..)

9. D: ¿se prefieren? (they prefer? -wrong form-)

10. M: le gusta a la gente (people like)

11. D: o ¿le gusta a la gente? Le gusta a..la gen[te (or people like? people..like)

12. M: [te, ah..

13. D: las comidas .. las comidas ¿rápidas? (food.. fast food?)

14. M: Sí, o creo que se usa la comida rápida, como [un tipo de comida (Yes, or I believe that they use fast food, as a type of food)

15. D: [oh, sí, la comida rápida, ok, la comida rápida ah (oh, yes, fast food, OK, fast food ah)

The collaboration begins with D's statement about people in the US liking food that you can, (que se puede) something, a thought which is completed by $\mathrm{M}$, who says preparar (prepare), which in turn is built upon immediately by $\mathrm{D}$, who adds muy rápidamente in $3 . \mathrm{M}$ then repeats rápidamente in 4 and relates this to restaurants, specifically los restaurantes de comida rápida, fast food restaurants, adding the affirmative sí. D concurs with the affirmative si and then repeats the phrase de comida rápida and from this point is able to seek clarification 
about the meaning of the phrase and the more complete idea of fast food restaurants restaurantes de comida rápida. With M's affirmative response in 6 , D says $O . K$ in 7 , which we see functioning as a marker of not only agreement and/or approval but as a signal to begin the next element of the composition. Again, repetition serves to locate the next platform from which to work, in this case the phrase en los Estados Unidos, which occurred in line 1 and is repeated in line 7 twice. We note also that $\mathrm{D}$ uses the polite and hypothetical form podriamos twice in 7 as she begins to consider exactly what to say about fast food in the US and how to say it. When D considers using se impersonal, M says No in 8 and begins his own search for the proper form. Interestingly, M's hypothesizing is grounded in the same cognitive space as D's and this is evidenced in his repetition of the phrase en los Estados Unidos and by D's subsequent completion of the phrase with the words se prefieren in 9. Thus, from the platform created by repetition of en los Estados Unidos hypotheses are proposed and tested. Note that $\mathrm{D}$ utters se prefieren in 9 with question intonation. Working on the same platform, $\mathrm{M}$ then offers the phrase le gusta a la gente in 10. Repetition of this phrase by $\mathrm{D}$, first in question form and then in an assertion accompanied by $\mathrm{M}$ with the final syllable te (in 11 and 12 respectively) creates another platform from which to take care of the next bit of work, using the correct form in which to express fast food. D offers the form las comidas rápidas in 13 with question intonation. $\mathrm{M}$ then suggests another saying creo que se usa la comida rápida. $\mathrm{D}$ agrees that this is the form and repeats the form. D then says $O K$, again as if it were a signal to begin the next element of the composition. Interestingly, repetition of la comida establishes the platform from which the work is to be continued.

\subsection{Intersubjectivity}

With advanced-level students, L2 is observed to be an effective mechanism to establish and maintain intersubjectivity, a shared orientation of the task. For instance, in Episode 3, we observe a rather sophisticated use of L2 as a mediating device to create a common cognitive plan, to negotiate goals and subgoals, and to maintain a harmonious working atmosphere in which both students contribute ideas and freely exchange suggestions, corrections and elaborations for each other's efforts.

\section{EPISODE 3}

1. M: OK. Bueno, ¿por qué no..?.. podemos organizarlo de..bueno, hay muchos deportes, no sé qué, algunos son deportes de equipos y otros de deportes para..[competencias

(OK. Well, why not..?.. We can organize it..well, there are many sports, blah, blah, some are team sports and others are sports for.competition)

2. S: [Hay mu-chos equipos..de...individuales?

(There are ma-ny teams..of..individual?)

3. M: equipos y deportes ind-individuales, bien (teams and ind-individual sports, good)

4. S: y los de y los olímpicas son ?? populares también? (and those and the olimpic (??) popular also?)

5. M: sí (yes)

6. S: ¿ponemos algo de eso o no? (shall we put some of that or not?) 
7. M: sí, OK, ah..OK, bueno, vale y podemos hablar de que..en nuestra, en nuestro país, ah, los jugadores de deportes ganan muchísimo dinero, demasiado, más que los art-artistas y y escritores y nadie y..

(yes, OK, ah..OK, well, OK and we can talk about..in our -feminine ending-, in our -masculine ending-country, ah, sport players make a lot of money, too much, more than art- artists and and writers and anybody else and..)

8. S: pero, sobre todo ah.. en el corazón de los ah..jugadores ah.. está el espíritu, no sé, para ganar por sí mismos

(but, above all ah..in the hearts of the ah..players ah..is the spirit, I don't know, to win by themselves)

9. M: ahmm, ganar.. no dinero sino, ahmm, lo bueno en, OK... entiendo lo que dices (ahmm, win..not money but, ahmm, the good in, OK...I understand what you mean)

10. S: sí, yo tenía unos..

(yes, I had some..)

11. M: pues, podemos empezar con ah..todos saben que en los Estados Unidos los deportes son muy importantes?

(then, we can start with.ah everybody knows that in the United States sports are very important?)

12. S: sí (yes)

(LATER)

25. M: OK. Ah..ah ¿por qué no antes quizás? Sería más fácil hablar de, mencionar los deportes de que vamos a hablar por ejemplo..ah,

(OK. Ah..ah, why not before maybe? It would be easier to speak of, to mention those sports that we are going to talk about, for instance...ah)

26. S: aha

27. M: O.K. Entonces decimos algo como..ah, el baloncesto, el fútbol americano, el tenis, oh no, estos dos son los de equipos y hockey..

(OK. So, we say something like...ah, basketball, football, tennis, oh no, these two are team sports and hockey)

28. S: ahmm

29. M: baloncesto y [fútbol americano y

(basketball and american football and...)

30. S: [puedes, puedes mencionar las diferencias

(you can, you can mention the differences)

31. M: oh, sí

(oh, yes)

32. S: pero no habla más de..

(But it doesn't say more of..)

33. M: OK. Entonces queremos ..decir..

(OK. So, we want to ...say..)

34. S: antes que 'hay razones esp..ecíficos' vamos a decir ..

(Before 'there are spe..cific reasons' we are going to say..)

35. M: el balon-, el fútbol americano, oh! Béisbol me.., algo tan importante como eso, el béisbol, fútbol americano y baloncesto son tres de los deportes, ah, con equipos (basket-, football, oh! beisball.. something as important as that, beisball, football and basketball are three of the sports, ah, with teams)

36. S: sí, con equipos

(yes, with teams) 
37. M: OK. El..

(OK. The..)

38. S: pues vamos a decir ahí, ah, vamos a hablar de las, de dos tipos de deportes.

(Then, we are going to say there, ah, we are going to talk about, about two types of sports)

In this excerpt we observe two students using L2 to achieve intersubjectivity with respect to the task in general. The task is to write a composition about sports in the US. The attempt to achieve a shared understanding of the goals and structure of the task gets underway in 1 with M's use of the universal O.K, along with the Spanish Bueno to initiate the move in the interaction toward a discussion of organization: Podemos organizarlo. M suggests a way to categorize sports: algunos son deportes de equipos y otros de deportes para competencias, apparently trying to distinguish between team sports and sports played by individuals. $\mathrm{S}$ joins in with an attempt to clarify the distinction, with the suggestion equipos de iindividuales? $\mathrm{M}$ accepts the suggestion (in 3), taking the term individuales and using it to describe sports instead of teams, and thereby arriving at two categories, equipos y deportes ...individuales, for the paper. $\mathrm{M}$ also indicates agreement and approval explicitly by adding bien. $\mathrm{S}$ then adds another category for consideration, olympic sports, los olímpicas. M indicates agreement by saying Sí. S then makes an inquiry about what they have discussed thus far and its value to the task: ¿ponemos algo de eso o no?, essentially asking if they should use these ideas or not. M says Sí. At this point the students have not actually composed anything; rather, they are developing a mutually agreed upon plan of action. The plan takes another step in 7 with M suggesting (politely with the use of podemos) that they discuss the players and how much money they earn en nuestro país...los jugadores de deportes ganan muchísimo dinero. $\mathrm{S}$ adds comments about the heart and spirit of the players (el corazón...el espiritu), to which $\mathrm{M}$ agrees (No dinero sino...Entiendo lo que dices). Having reached agreement thus far, $\mathrm{M}$ then suggests in 11 (again with the polite and hypothetical form podemos) how to begin the composition: podemos empezar con ....todos saben .... S responds with Sí. Later in $25 \mathrm{M}$ makes another organizational suggestion: Sería más fácil hablar de, mencionar los deportes de que vamos a hablar por ejemplo. Subsequently, after listing various specific sports, the students reiterate their goal to list sports into general categories. Thus in line $38 \mathrm{~S}$ says ...vamos a hablar de las, de los dos tipos de deportes, i.e., two types of sports, referring to team sports and individual sports.

The students have used the L2 to establish the subgoals of the writing task: to categorize sports, to discuss players and what they play for (money or 'heart'), to begin with a statement about the importance of sports in the US and an introduction of the sports that will be discussed. What we find interesting about this interaction is that L2 takes on the mediational role of language that sociocultural theory finds so critical in learning situations. Specifically, here the L2 is the vehicle for establishing intersubjectivity, which according to Wertsch (1985: 159 ) is achieved when «interlocutors share some aspect of their situation definitions», i.e., when individuals working in collaboration define the objects (both concrete and abstract), events and goals of a task in the same way.

\section{EPISODE 4}

(In Episode 4 the students turn to the question of how to conclude the task.) 
1. M: debemos buscar una manera de ah..

(We must look for a way to ah..)

2. S: ¿concluir?

(Conclude?)

3. M: Sí, ah...

(Yes, ah...)

4. S: Lo más important- a mí es más importante que los jugadores juegan los deportes por?

(The most important- to me it is more important that players play sports for?)

5. M: OK, ah, lo, cada uno tiene su propio deporte, cada..uno..tiene..su..propio..deporte.. or propia deporte favorit- or ipreferido?

(OK, ah. the, everyone has their own sport, every..one..has..their.own..sport..or own-feminine ending- favorit- sport or preferred?)

6. S: Sí

(Yes)

7. M: Ah..ah, lo importante

(Ah..ah, what's important)

8. S: No olvidas, no olvida que lo importante debe ser..

(Don't forget, don't forget that what must be important..)

9. M: o, o.. ah, or todos, todos los deportes, ah, pue- podemos aprender la buena salud..o como de, podemos decir algo de.

(or, or..ah, or all, all sports, ah, ca-we can learn good health..or like, we can say something about..)

10. S: podemos aprender a cómo ser ah..buena forma..

(we can learn how to be -wrong verb-ah..good shape..)

11. M: prender, aprender de estar o ¿de estar en buena forma?

(-earn, learn to be or to be in good shape?)

12. S: aha

13. M: en buena forma, físicamente, ah...en la física y en la mental?

(in good shape, physically, ah, physically and mentally?)

14. S: con respecto a la mente

(with respect to the mind)

15. M: con, OK, con respecto a..la..mente

(with, $\mathrm{OK}$, with respect to..the..mind)

16. S: mente y cuerpo

(mind and body)

17. M: y cuer-po, ah.. ¿por los deportes?

(and bo-dy, ah..because of sports?)

18. S: a causa de

(due to)

19. M: a causa, gracias, a causa de los deportes

(due to, thank you, due to sports)

20. S: Punto final.

(Period)

Interestingly, we observe that having worked through the task together, the students have achieved a level of intersubjectivity which is evident in the way they now undertake the subgoal of ending the task, i.e., M's utterance in 1 debemos buscar una manera de...ah.. is completed by S , who asks in 2 ¿concluir? S suggests they conclude with some statement about 
the importance of playing sports. M concurs and now, having agreed on the goal of the conclusion, the students begin the work of achieving the goal. They come to the question of what the importance of sports really is: in $8 \mathrm{~S}$ says ...que lo importante debe ser. M suggests, again using the polite/hypothetical form podemos, that the importance of sports is good health la buena salud in 9. Unsure how to phrase this, M begins to propose saying something, podemos decir algo de, and $\mathrm{S}$ completes the proposal in 10 with repetition of part of M's first suggestion podemos aprender and a change from simply la buena salud to a como ser ah..buena forma. M picks up the thought with the repetition of aprender, prender, aprender and from that point (in the scaffold) builds on what has been said thus far by proposing, this time in the form of a question, ¿de estar en buena forma? S signals agreement with the utterance Aha. $\mathrm{M}$ continues with repetition of buena forma, now apparently a fixed point in the scaffold, and from there offers new material for consideration, with question intonation: fisicamente, ah, ¿en la fisica y en la mental? S responds with another possibility: con respecto a la mente. $\mathrm{M}$ accepts the suggestion and repeats it; con, OK, con respecto a la mente. The interaction of two individuals now takes on the appearance of the externalization of the thoughts of a single person as the students pick up, repeat, and build on each others' utterances, having achieved a very effective level of cognitive intersubjectivity. Thus, $\mathrm{S}$ continues by first repeating mente and adding to it $y$ cuerpo. $\mathrm{M}$ takes up the scaffolded help by repeating $y$ cuerpo and from there suggests with a question ¿por los deportes? S accepts the idea of one additional phrase attributing good mental and physical health to sports but suggests a different form: a causa de. $\mathrm{M}$ accepts the form by repeating it a causa and saying gracias and then repeats the entire phrase: a causa de los deportes. S brings the task to a close with Punto Final.

\section{Conclusion}

In the collaborative interaction of the L2 advanced-level students examined here, the L2 is used for a variety of social and cognitive functions serving the purpose of providing scaffolding for each other and maintaining intersubjectivity. We have been able to identify some of the communicative mechanisms that contribute to achieving effective collaboration: repetition, use of modals, questioning. These are similar to the discursive mechanisms observed in the interaction of beginning-level students completing the same tasks. The crucial difference is that at the advanced level, students (these students at least) are predominantly using L2 for functions that go far beyond the mere creation of content for their texts ${ }^{4}$. The L2 emerges in the interaction as the principal mediating device to negotiate meaning, language forms, and task goals and procedures, thus offering opportunities to use the L2 in ways that may not be available in a non-collaborative setting.

4 We do not want to suggest that being "advanced learners" means that all such students will use their L2 in the way our participants have. The following studies, for example, demonstrate that the use of L1 by advanced learners is also likely to occur in similar tasks: Alley (2005), Centeno Cortes \& Jimenez Jimenez (2004), Potowski (2004), and Swain \& Lapkin (1998). 


\section{References}

Ahmed, M. (1994): «Speaking as cognitive regulation: a Vygotskian perspective on dialogic communication». In Lantolf, J. \& G. Appel (Eds.): Vygotskian approaches to second language research. Norwood, NJ, Ablex, págs. 157-171.

Aljaafreh, A. \& J. P. Lantolf. (1994): «Negative feedback as regulation and second language learning in the zone of proximal development», The Modern Language Journal ,78, págs. 465-483.

Alley, D. (2005): «A study of Spanish II high school students' discourse during group work,» Foreign Language Annals, 38.2, pp. 250-257.

Antón, M. \& F. J. DiCamilla. (1998): «Socio-cognitive functions of L1 collaborative interaction in the L2 classroom», The Canadian Modern Language Review, 54, págs. 314-42.

Behrend, D. A., K. S. Rosengren \& M. Perlmutter. (1992): «The relation between private speech and parental interactive style». In Diaz, R, \& L. E. Berk (eds.): Private speech: From social interaction to self-regulation. Hillsdale, NJ, Lawrence Erlbaum, págs. 85-100.

Brooks, F. B. \& R. Donato. (1994): «Vygotskyan approaches to understanding foreign language learner discourse during communicative tasks», Hispania, 77, págs. 262-274.

Brooks, F. B., R. Donato \& J. V. McGlone. (1997): «When are they going to say 'it' right? : understanding learner talk during pair-work activity», Foreign Language Annals, 30, págs. 523-541.

Buckwalter, P. (2001): «Repair sequences in Spanish L2 dyadic discourse: A descriptive study», The Modern Language Journal, 85.3, págs. 380-397.

Centeno Cortés, I. \& A. Jiménez Jiménez. (2004): «Problem-solving tasks in a foreign language: The importance of the L1 in private verbal thinking», International Journal of Applied Linguistics, 14, págs. 7-35.

De Guerrero, M. C. M. (1994): «Form and function of inner speech in adult second language learning». In Lantolf, J. \& G. Appel (eds.), Vygotskian approaches to second language research. Norwood, NJ, Ablex, págs. 83-116.

De Guerrero, M.C.M \& O.S. Villamil. (1994): «Social_cognitive dimensions of interaction in L2 peer revision», The Modern Language Journal, 78, págs. 484-496.

De Guerrero, M.C.M \& O.S. Villamil. (2000): «Activating the ZPD: mutual scaffolding in L2 peer revision», The Modern Language Journal, 84, págs. 51-68.

Diaz, R. M., C. J. Neal \& A. Vachio. (1991): «Maternal teaching in the zone of proximal development: A comparison of low-and-high-risk dyads», Merrill Palmer Quarterly, 37, págs. 83-108.

DiCamilla, F. J. \& M. Antón (1997): «The function of repetition in the collaborative discourse of L2 learners», The Canadian Modern Language Review, 53, págs. 609-33.

DiCamilla, F. J. \& M. Antón (2004): «Private speech: A Study of Language for Thought in the Collaborative Interaction of Language Learners», International Journal of Applied Linguistics, 14.1, págs. 36-69.

DiCamilla, F. J. \& J. P. Lantolf (1994): «The linguistic analysis of private writing», Language Sciences, 16, págs. 347-369.

Donato, R. (1994): «Collective scaffolding in second language learning». In J.P. Lantolf and G. Appel (eds.): Vygotskian approaches to second language research. Norwood, NJ, Ablex, págs. 33-56.

Duff, P. (2000): «Repetition in foreign language classroom interaction». In Hall, J.K. \& L. S. Verplaetse (eds.): Second and Foreign Language Learning through Classroom Interaction. Mahwah, NJ, Lawrence Erlbaum. 
Frawley, W., \& J. P. Lantolf. (1985): «Second language discourse: A Vygotskyan perspective», Applied Linguistics, 6, págs. 19-44.

Gánem Gutiérrez, A. (2008): «Microgenesis, method and object: A study of collaborative activity in a Spanish as a foreign language classroom», Applied Linguistics, 29/1, págs. 120-148.

John-Steiner, V. (1987): Notebooks of the mind: Exploration of thinking. New York, Harper and Row.

Kinginger, C. (2002): «Defining the zone of proximal development in US foreign language education», Applied Linguistics, 23/2, págs. 240-261.

Lantolf, J.P. \& S. Thorne (2006): Sociocultural Theory and the Genesis of Second Language Development. Oxford, Oxford University Press.

Matusov, E. (1996): «Intersubjectivity without agreement», Mind, Culture, and Activity, 3 (1), págs. 25-45.

McCafferty, S. (1992): «The use of private speech by adult second language learners: A cross-cultural study», The Modern Language Journal, 76, págs. 179-188.

McCafferty, S. (1994): «The use of private speech by adult ESL learners at different levels of proficiency». In Lantolf, J. \& G. Appel (eds.): Vygotskian approaches to second language research. Norwood, NJ, Ablex, págs. 117-134.

Ohta, A. S. (1995): «Applying sociocultural theory to an analysis of learner discourse: learner-learner collaborative interaction in the zone of proximal development», Issues in Applied Linguistics, 6 , págs. 93-122.

Ohta, A. S. (2000): «Rethinking interaction in SLA: Developmentally appropriate assistance in the zone of proximal development and the acquisition of L2 grammar». In Lantolf, J. P. (ed.): Sociocultural theory and second language learning». Oxford, Oxford University Press, págs. 51-78

Ohta, A. S. (2001): Second language Acquisition Processes in the Classroom: Learning Japanese. Mahwah, NJ, Lawrence Erlbaum.

Platt, E. \& F. B. Brooks (1994): «The 'acquisition-rich environment' revisited», The Modern Language Journal, 78, págs. 497-511.

Pellegrini, A. D. (1981): «The development of preschoolers' private speech», Journal of Pragmatics, 5 , págs. 445-458.

Potowski, K. (2004): «Student Spanish use and investment in a dual immersion classroom: Implications for second language acquisition and heritage language maintenance», The Modern Language Journal, 88 , págs. $75-101$.

Radziszewska, B., \& B. Rogoff. (1991): «Children’s guided participation in planning imaginary errands with skilled adult or peer partners», Developmental Psychology, 27, págs. 381-397.

Rommetveit, R. (1974): On message structure: A framework for the study of language and communication. New York, Wiley.

Rommetveit, R. (1979): «On codes and dynamic residuals in human communication». In Rommetveit, R. \& R.M. Blakar (Eds.): Studies of language, thought and verbal communication. Orlando, FL, Academic Press, pp. 163-175.

Rommetveit, R. (1985): «Language acquisition as increasing linguistic structuring of experience and symbolic behavior control.» In Wertsch, J. (ed.): Culture, communication, and cognition. Cambridge, Cambridge University Press, págs. 183-204.

Schinke-Llano, L. (1994): «Linguistic accommodation with LEP and LD children». In Lantolf, J. \& G. Appel (eds.): Vygotskian approaches to second language research. Norwood, NJ, Ablex, págs. 57-68. 
Stetsenko, A. P. (1999): «Social interaction, cultural tools and the zone of proximal development: in search of a synthesis». In Chaiklin, S., M. Hedegaard and U. J. Jensen (eds.): Activity Theory and Social Practice: Cultural Historical Approaches. Aarhus, Aarhus University Press, págs. 235-252.

Stone, C. A. (1993): «What is missing in the metaphor of scaffolding?». In Forman, E., N. Minick \& C. A. Stone (eds.): Contexts for learning. Sociocultural dynamics in children's development. Oxford, Oxford University Press, págs. 169-183.

Swain, M. \& Lapkin, S. (1998): «Interaction and second language learning: Two adolescent French immersion students working together», The Modern Language Journal, 83, págs. 320-338.

Villamil, O.S. \& M. C. M. de Guerrero. (1996): «Peer revision in the L2 classroom: Social-cognitive activities, mediating strategies, and aspects of social behavior», Journal of Second Language Writing, 5, pp. 51-75.

Vygotsky, L. S. (1978): Mind in society: The development of higher psychological processes (Cole, M., V. John-Steiner, S. Scribner, \& E. Souberman (eds.). Cambridge, MA, Harvard University Press.

Vygotsky, L. S. (1981): «The genesis of higher mental functions.» In Wertsch, J. V. (ed. and trans.): The concept of activity in Soviet psychology. Armonk, N.Y, M. E. Sharpe, págs. 144-188.

Vygotsky, L. S. (1986): Thought and Language. (Kozulin, A. Ed.) Cambridge, MA, MIT Press.

Wertsch, J. V. (1979): «The regulation of human action and the given-new organization of private speech». In Zivin, G. (ed.): The development of self-regulation through private speech. New York, Wiley, págs. 79-98.

Wertsch, J. V. (1985): Vygotsky and the Social Formation of Mind. Cambridge, MA, Harvard University Press.

Wertsch, J. V., N. Minick, \& F. J Arns. (1984): «The creation of context in joint problem-solving». In Rogoff, B. \& J. Lave (eds.): Everyday cognition: Its development in social context. Cambridge, MA, Harvard University Press.

Wood, D., J. S. Bruner, \& G. Ross. (1976): «The role of tutoring in problem solving», Journal of Child Psychology and Psychiatry, 17, págs. 89-100. 